UDC 550.814:528.8.04

\title{
Urban thermal micro-mapping using satellite imagery and ground-truth measurements: Kyiv city area case study
}

\author{
I. O. Piestova ${ }^{1, *}$, M. S. Lubskyi ${ }^{1}$, M. O. Svideniuk ${ }^{1}$, S. I. Golubov ${ }^{1}$, O. A. Laptiev ${ }^{2}$ \\ ${ }^{1}$ Scientific Centre for Aerospace Research of the Earth Institute of Geological Science National Academy of Sciences of Ukraine, Kyiv, Ukraine \\ ${ }^{2}$ State University of Telecommunications, Kyiv, Ukraine
}

The aim of this research is to enhance approaches existing for the assessment of cities thermal conditions under climate change impact by using multispectral satellite data for Kyiv city area.

This paper describes the method and results of the Earth's surface temperature (LST) and thermal emissivity calculation. Particularly, the thermal distribution was estimated based on spectral densities according to Planck's law for "grey bodies" by using the Landsat-8 TIRS and Sentinel-2 MSI satellite imagery. Furthermore, the result was calibrated by ground data collected during the ground-truth measurements of the typical city surfaces temperature and thermal emissivity.

The spatial resolution of the LST images obtained was enhanced by using the approach of subpixel processing, that is the pairs of invariant images shifted with subpixel accuracy. As a result, such an approach allowed to enhance the spatial resolution of the image up 46\%, which is much higher than the potential performance of the thermal imaging sensors existing.

The interrelation between the Earth's surface type and the temperature was revealed by the results of the Sentinel-2A MSI image of 21 August 2017 supervised classification. Thus, the image was divided into the six major classes of the urban environment: building's rooftops, roads surface, bare soil, grass, wood, and water. As a result, surfaces with vegetation much more cool next to artificial ones.

The time-series analysis of 18 thermal images (Landsat TM and Landsat-8 TIRS) of Kyiv for the period from 6 Jun 1985 till 1 June 2018 was done for spatiotemporal changes investigation. Therefore, the sites of the LST thermal anomalies caused by landscape changes were developed. Among them are the sites of increased LST where thw "Olimpiyskiy" national sport center and adjacent parking was built and the site of decreased LST where the tram depot was liquidated and the territory was flooded. Keywords: city thermal regime, land surface temperature, thermal radiation emissivity, time series

(c) I. O. Piestova, M. S. Lubskyi, M. O. Svideniuk, S. I. Golubov, O. A. Laptiev. 2019

DOI: https://doi.org/10.36023/ujrs.2019.21.149

\section{Introduction}

With the advent of residential landscapes began an active process of the anthropogenic landscapes formation. In such a peculiar environment, people and technology are the main sources for the further formation of the environment state [3]. In particular, anthropogenic activities cause the temperature contrasts between the urban environment and the surrounding territories. Among the factors that form the city thermal field are:

- artificial covers that are characterized by high heat capacity $[8,11]$, and over the total area they considerably exceed the area of green plantings [1];

- high concentrations of harmful emissions that change the radiation properties of the atmosphere, forming an environment in which the thermal field dissipates much slower;

- dense building, which leads to blocking of wind flows, and therefore prevents convective cooling [7].

Mapping the land surface temperature distribution according to earth remote sensing allows delineate area, which characterized by abnormally high temperatures - the so-called "heat island", and also

*E-mail: ipestova@casre.kiev.ua

Online ISSN 2313-2132 identify the influence efficiency landscaping to reduce thermal pollution $[6,11,14]$.

\section{Objective}

The primary basis of this study is the determination of long-term changes in the surface temperatures distribution within the urbanized environment on the example Kyiv city. Previous studies of this problem were carried out jointly with the St. Petersburg Research Center for Environmental Safety of the RAS [4, 5]. In the framework of these works, long-term data series of the longwave infrared remote sensing data received by the Landsat and EOS satellites have been processed. As a result, a trend to increase both surface and atmospheric temperature within the urban environment has been revealed and the negative consequences for the city microclimate and public health have been studied. These works have encouraged the implementation of the following studies on the impact of urbanization on the temperature regime of the urban environment.

This study is aimed at solving the problem of providing a quantitative assessment of the current state of the thermal regime of Kyiv by mapping the surface temperature distribution based on the processing of 
Earth remote sensing data. In addition, an attempt was made to assess the influence of environmental factors and types of landscapes on the city thermal regime. Particular attention is paid to the influence of green areas on the microclimate and the dynamics of their density within Kyiv.

The purpose of this work is to improve the assessment of the thermal regime of the city in the context of climate change using infrared satellite imagery.

\section{Input data}

\section{Satellite imagery}

In this study, long-wave infrared images of Landsat series satellite systems $(5,7,8)$ were used (https:// earthexplorer.usgs.gov/). The imagery of the long-wave infrared radiation from the Thematic Mapper (TM) and Enhanced Thematic Mapper Plus (ETM +) sensors of the Landsat -5 and Landsat- 7 satellites have a spatial resolution of 120 and $60 \mathrm{~m}$, respectively, and the dualband images of the TIRS satellite of the Landsat- 8 satellite have a spatial distribution of $100 \mathrm{~m}$. The imagery of visible, near-infrared (VNIR) and short-wave (SWIR) bands with a spatial distribution of $30 \mathrm{~m}$ were obtained from the results of imaging by the above-mentioned TM, ETM+ sensors, as well as the Operational Land Imager (OLI) sensor installed on Landsat-8 satellite.

To increase the spatial resolution of the thermal field images, satellite multispectral optical imagery from Sentinel-2 Multispectral Instrument (MS) were downloaded. An optical sensor is installed on this satellite, which conducts imaging in thirteen spectral bands from VNIR to SWIR (https://scihub.copernicus.eu/dhus/\#/home).

During the May-August 2018 period, 6 Landsat-8 thermal images were processed, from which the temperature distribution image was obtained. The results of processing two Sentinel-2 images (for May 28 and August 11) were used as the thermal radiation emissivity distribution sources. Post processed images codenames are listed in Table 1 (land surface emissivity date) and Table 2 (land surface temperature data).

In order to analyse the time series, retrospective satellite images of the Kyiv city territory from 1985 to

Table 1.

List of processed images

\begin{tabular}{lc}
\hline \multicolumn{1}{c}{ Image Name } & Space survey date \\
\hline \multicolumn{1}{c}{ Landsat-8 } \\
LC08_L1TP_181025_20180601_20180614_01_T1 & 1 June 2018 \\
LC08_L1TP_182025_20180608_20180615_01_T1 & 8 June 2018 \\
LC08_L1TP_182025_20180710_20180717_01_T1 & 10 July 2018. \\
LC08_L1TP_181025_20180804_20180814_01_T1 & 4 August 2018 \\
LC08_L1TP_182025_20180811_20180815_01_T1 & 11 August 2018 \\
LC08_L1TP_181025_20180820_20180829_01_T1 & 20 August 2018 \\
\hline \multicolumn{1}{c}{ Sentinel-2 } \\
\hline S2A_MSIL2A_20180528T085641_N0208_R007_T35UQS_20 180528T112050 \\
S2B_MSIL2A_2018081 1T085549_N0208_R007_T35UQS_20180811T134626 \\
\hline
\end{tabular}

Table 2.

List of Landsat images used to analyse time series

\begin{tabular}{|c|c|}
\hline Image archive iden tifier & Space survey date \\
\hline LT05 L1TP 1810251985060620170219 01 T1 & 6 June1985 \\
\hline LT05_L1TP_181025_19880630_20180210_01_T1 & 30June 1998 \\
\hline LT04_L1TP_181025_19890711_20170202_01_T1 & 11 July 1989 \\
\hline LT05_L1TP_181025_19900807_20170129_01_T1 & 7 August 1990 \\
\hline LT05_L1TP_181025_19920828_20180218_01_T1 & 28August 1992 \\
\hline LT05_L1TP_181025_19930815_20170117_01_T1 & 15 August 1993 \\
\hline LT05_L1TP_181025_19950602_20170107_01_T1 & 2 June 1995 \\
\hline LT05_L1TP_181025_19960706_20180219_01_T1 & 6 July 1996 \\
\hline LT05_L1TP_181025_19970810_20180218_01_T1 & 10August 1997 \\
\hline LT05_L1TP_181025_20020621_20161208_01_T1 & 21 June 2002 \\
\hline LT05_L1TP_181025_20050731_20161124_01_T1 & 31 July 2005 \\
\hline LT05_L1TP_181025_20070822_20161111__01_T1 & 22 August 2007 \\
\hline LT05 L1TP 1810252008080820161030 01 T1 & 8 August 2008 \\
\hline LC08 L1TP $1810252014060620170422^{-} 01^{-} \mathrm{T} 1$ & 6 June 2014 \\
\hline LC08_L1TP_181025_20150828_20170405_01_T1 & 28August 2015 \\
\hline LC08_L1TP_181025_20160713_20170323_01_T1 & 13July 2016 \\
\hline LC08_L1TP_181025_20170817_20170826_01_T1 & 26August 2017 \\
\hline LC08_L1TP_181025_20180601_20180614_01_T1 & 1 June 2018 \\
\hline
\end{tabular}


2018 were downloaded, according to the results of the Landsat survey.

Mainly, satellite images were selected after an assessment of cloudiness: no more than 10\% cloudiness during the survey.

\section{Field measurements data}

During the June-August 2017 and 2018 period, ground-based measurements work was carried out to create a database of temperature indicators and the thermal radiation emissivity of typical artificial and natural city covers.

Mainly, ground data was collected in relatively homogeneous areas, which allowed to recognize the signal of the selected cover in a $2 \times 2$ pixel window of the resulting Sentinel-2 image (Fig 1). Remote sensing and measuring the temperature of the land surface were carried out remotely - using a Fluke Ti110 thermal imager and a Trotec TP10 pyrometer, as well as contact measurements mode using a Benetech GM1312 thermometer equipped with two thermocouple elements. This approach allows determining both the brightness temperature remotely using the built-in microbolometer sensor of infrared radiation, and directly contact thermodynamic temperature using a thermometric instrument. Ground measurements data are in Table 3.

\section{Research methods}

\section{Land surface temperature calculations}

Determination of the objects temperature and the earth's surface covers by processing the data of infrared removal is achieved by using the inverse Planck law for the "gray body" to express the temperature through the spectral density of the radiation flux provided by the satellite system [12-15]:

$$
T=\frac{c_{2}}{\lambda \ln \left(\frac{\varepsilon(\lambda) c_{1}}{\lambda^{5} L_{s}}+1\right)}
$$

where Ls is the spectral radiance of the land surface, $\varepsilon$ $(\lambda)$ is the thermal radiation emissivity, $c_{1}=2 b c^{2}=1.191 \cdot 10^{-16} \mathrm{~W} \cdot \mathrm{m}^{2}$ and $c^{2}=\frac{b c}{k}=1.439 \cdot 10^{-2}$ $\mathrm{m} \cdot \mathrm{K}$ - are the first and second radiation constants, $\mathrm{h}=$ $6.626 \cdot 10-34 \mathrm{~J} \cdot \mathrm{s}-$ is the Planck's constant, $\mathrm{c}=2.998 \cdot$ $10^{8} \mathrm{~m} / \mathrm{s}-$ is the light speed of light in vacuum, $\lambda-$ is wavelength of electromagnetic radiation.

Usually, equation (1) is customized using the $\mathrm{K}_{1}$ and $\mathrm{K}_{2}$ hardware constants, specified for a current sensor, as established during laboratory calibration [2]. In this study, in order to improve the detail of the Earth's surface, the Sentinel-2 MSI were used in the thermal distribution calculation model.
To determine the distribution of the thermal radiation emissivity by remote sensing data were selected cloudless Sentinel-2 MSI image were selected. Thus, from the obtained two images of the distribution of the coefficient of thermal radiation emissivity, the first (up to May 28, 2018) was used to calculate temperature images based on Landsat-8 data for the first half of summer (before July 10), and the second (until August 11, 2018) - for the other three (4-20 August 2018) (Fig. 2).

Such an approach is appropriate since the coefficient of thermal radiation emissivity is considered to be a rather inert value, for a long time (within 1-2 months) remains unchanged for surfaces covered with vegetation, and absolutely static for artificial surfaces provided it remains unchanged (due to building or other drivers). With more cloudless images should use all possible to reduce the influence of unrecorded surface modifications that are possible at the research period.

\section{Spatial resolution enhancement}

To improve the detail of thermal field images, the method of sub-pixel processing was applied. In this case, sub-pixel offset invariant image pairs were used (multi-temporal distributions of thermal radiation emissivity and temperature [4] as a high resolution and low resolution component of the image respectively). This superresolution approach makes it possible the spatial resolution enhancement by $45-50 \%$ of the original images [9, 10].

To improve the detail of the image of the Kiev's thermal field, the Sentinel-2 MSI images with10 m spatial resolution were used to calculate the thermal radiation emissivities (for comparison, the Landsat-8 OLI VNIR images have a spatial resolution of $30 \mathrm{~m}$ ) (Fig. 3).

\section{Time series analysis of Earth remote sensing data}

Advantage of the time series analysis implementation the possibility of trend detection by remote data. Thus, four main time series parameters of the of remote data have to be calculated: the average value of the studied indicator for all time period, the average increment of the studied indicator at a certain time interval, the contribution of fluctuations of a certain period in the total periodic component of the time series and the significant period [16]. Time series analysis is performed for each element of the land surface separately, as a result of which four spatial distributions of each of the time series parameters are obtained in the same geometry as input time series images.

\section{Results}

As part of the study, a time series analysis was carried out from 18 thermal images (Landsat-5 TM and Landsat-8 OLI) of the Kyiv city for the period from June 6,1985 to June 1,2018 . The image of the dynamics 


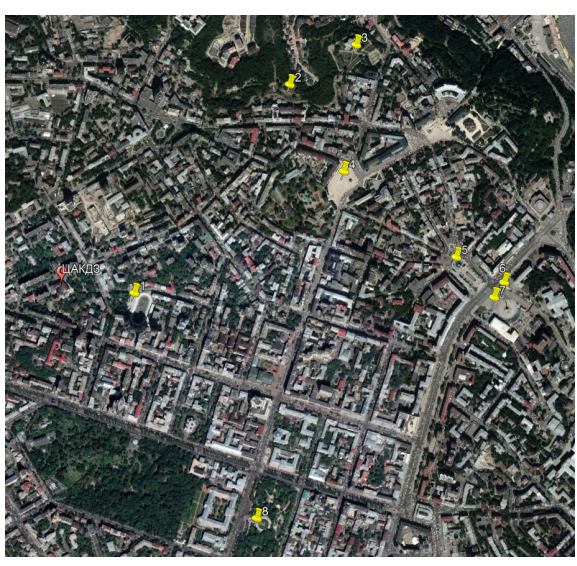

a

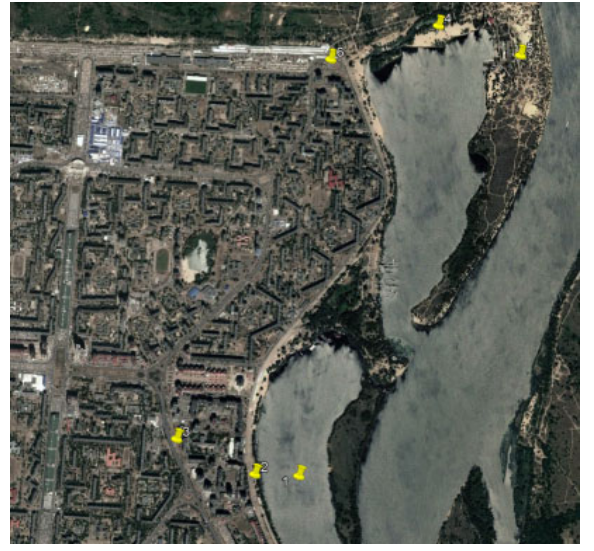

$\mathrm{b}$

Fig. 1. Experimental sites within Kyiv:

a - central part: 1 - Kyiv cycle track (cobblestones), 2 - Landscape alley (lawn), 3 - Museum of Ukrainian History (cobblestones), 4 - Sofia square (cobblestones), 5 - Independence Square (pavers), 6 - Alley of Heavenly Hundreds (asphalt), 7 - Maydan Nezalezhnosti (pavers), 8 Shevchenko Park (pavers);

b - within the Obolon micro district: 1 - Obolon Bay (water), 2 - coastline (pavers), 3 - Prospect Heroes of Stalingrad avenue (asphalt), 4 Bay Dog mouth (sand), 5 - Canal Bay (sand with sparse vegetation), 6 - bus depot (asphalt)

Table 3.

Results of measurements of temperatures and thermal radiation coefficients from remote sensing data and ground-based measurements

\begin{tabular}{|c|c|c|c|c|c|c|}
\hline Surface type & $\varepsilon^{1}$ & $\begin{array}{l}\operatorname{Trad}^{2} \\
(\mathrm{C})\end{array}$ & $\begin{array}{l}\mathrm{Td}^{3} \\
(\mathrm{C})\end{array}$ & $\begin{array}{l}\mathrm{Td}_{\mathrm{rS}}{ }^{4} \\
\left({ }^{\circ} \mathrm{C}\right)\end{array}$ & $\begin{array}{l}\mathrm{Td}_{\mathrm{GM}}{ }^{5} \\
\left({ }^{\circ} \mathrm{C}\right)\end{array}$ & $\begin{array}{l}\mathrm{Td}_{\mathrm{GM}}-\mathrm{Td}_{\mathrm{RS}} \\
\left({ }^{\circ} \mathrm{C}\right)\end{array}$ \\
\hline Lawn & 0.946 & 28.73 & 0.943 & 29.44 & 32.8 & 3.36 \\
\hline Asphalt & 0.926 & 41.7 & 0.985 & 37.86 & 42.8 & 4.94 \\
\hline Pavingstones & 0.956 & 35.52 & 0.969 & 38.86 & 37.8 & 1.06 \\
\hline Pavingstones & 0.931 & 42.55 & 1.042 & 38.99 & 39.5 & 0.51 \\
\hline Asphalt & 0.956 & 41.5 & 0.981 & 38.15 & 42.9 & 4.75 \\
\hline Pavingstones & 0.935 & 39.5 & 0.968 & 34.99 & 41.9 & 6.91 \\
\hline Pavingstones & 0.927 & 38.6 & 0.984 & 35.5 & 39.8 & 4.3 \\
\hline Water & 0.977 & 22.5 & 0.992 & 23.06 & 23.0 & -0.06 \\
\hline Asphalt & 0.928 & 41.64 & 0.973 & 40.1 & 43.7 & 3.6 \\
\hline Pavingstones & 0.932 & 41.8 & 0.987 & 37.21 & 42.8 & 5.59 \\
\hline Lawn & 0.961 & 28.2 & 0.959 & 28.93 & 31.1 & 2.17 \\
\hline Pavingstones & 0.955 & 38.75 & 0.980 & 39.22 & 40.2 & 0.98 \\
\hline Asphalt & 0.936 & 41.38 & 0.985 & 37.67 & 42.5 & 4.83 \\
\hline $\begin{array}{l}\text { Sand + } \\
\text { sparse vegetation }\end{array}$ & 0.935 & 37.5 & 0.973 & 38.4 & 39.5 & 1.1 \\
\hline Asphalt & 0.936 & 47.5 & 1.041 & 42.5 & 44.4 & 1.9 \\
\hline Sand & 0.93 & 44.02 & 0.988 & 41.0 & 44.9 & 3.9 \\
\hline $\begin{array}{l}\text { Sand + } \\
\text { sparse vegetation }\end{array}$ & 0.935 & 41.4 & 0.975 & 41.3 & 43.3 & 2.0 \\
\hline Asphalt & 0.936 & 42.7 & 0.979 & 42.04 & 44.3 & 2.26 \\
\hline Sand & 0.93 & 43 & 0.979 & 45.11 & 44.6 & -0.51 \\
\hline Water & 0.987 & 28.03 & 0.986 & 28.58 & 29 & 0.42 \\
\hline Lawn & 0.949 & 29.42 & 0.970 & 30.56 & 31.5 & 0.94 \\
\hline Asphalt & 0.926 & 41.45 & 0.985 & 37.41 & 42.6 & 5.19 \\
\hline Pavingstones & 0.931 & 34.6 & 0.970 & 35.56 & 36.8 & 1.24 \\
\hline Pavingstones & 0.956 & 34.61 & 1.017 & 36.38 & 33.4 & -2.98 \\
\hline Pavingstones & 0.931 & 37.13 & 0.960 & 38.38 & 40.1 & 1.72 \\
\hline Asphalt & 0.926 & 41.33 & 0.974 & 38.38 & 43.3 & 4.92 \\
\hline Pavingstones & 0.935 & 35.3 & 0.967 & 36.42 & 37.7 & 1.28 \\
\hline Pavingstones & 0.927 & 39.1 & 0.981 & 36.17 & 40.5 & 4.33 \\
\hline $\begin{array}{l}\text { Average } \\
\text { measurement } \\
\text { error }\end{array}$ & & & 0.035 & & & 2.769 \\
\hline
\end{tabular}

${ }^{1}$ The estimated value of the coefficient of thermal radiation emissivity $(\varepsilon)$ by remote sensing data

${ }^{2}$ Radiation temperature as results of field measurements

${ }^{3}$ Calculated thermodynamic temperature

${ }^{4}$ Thermodynamic temperature by remote sensing data processing

${ }^{5}$ Thermodynamic temperature by ground-truth measurements 


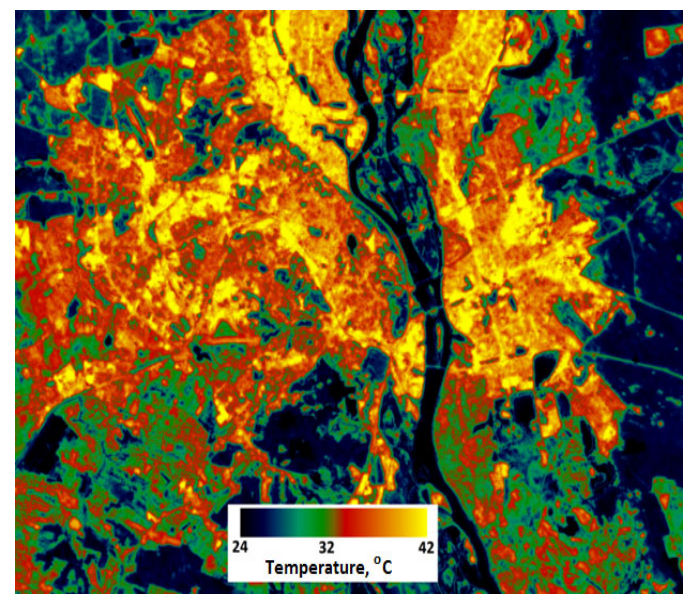

Fig. 2. Kyiv city temperature distribution according to Landsat-8 (August 2018) and Sentinel-2 (August 11)

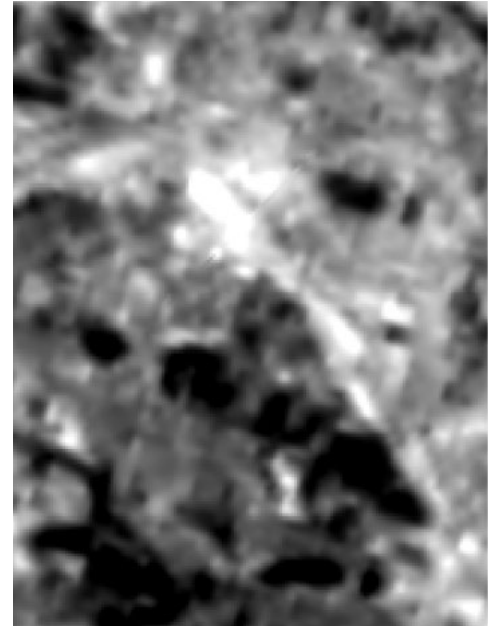

a

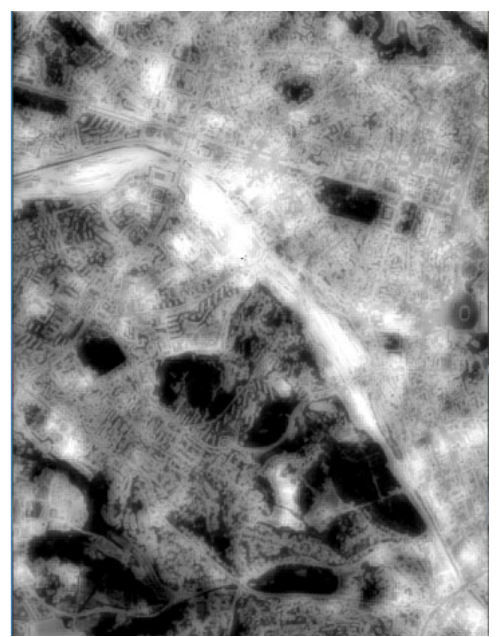

$\mathrm{b}$

Fig.3. The images detail comparison obtained using Landsat- 8 data (central part of the city. Kiev, August 4, 2018): a - input data of the 10th band; b - distribution of the temperature field obtained using Sentinel-2 data (August 11, 2018) for calculating the distribution of thermal radiation emissivity

of the surface temperatures within the Kyiv city during the research period is shown in Fig. 4.

Lowering Kharkov region reservoir cascade temperature (lakes Tyagle, Nebrej, Martishiv) due to their appearing in the 1990s because of sand for the construction development. This causes a significant increase in temperature (up to $14^{\circ} \mathrm{C}$ ) of a significant part north of the cascade. Such processes are also characteristic of the northern part of the Kyiv Left Bank, in the Troyeschina micro-district: the construction development causes of construction caused an increase in surface temperatures as well as a local decline in the Diamond Lake area due to its formation through the sand fence. It should also be noted about the presence of significant areas of forests around Kyiv, for which significant temperature increases have been found, which indicates an array of deforestation. Also within Kyiv there are a large number of small areas with significant temperature increases (up to $20^{\circ} \mathrm{C}$ ) due to the development of infrastructure: the construction of a shopping centre, the International Exhibition Centre, etc. The background increase in surface temperatures found in built-up areas did not change during the study period at approximately $3^{\circ} \mathrm{C}$.

The relationship between the type and temperature of the terrestrial surface was confirmed by analysing the results of the Sentinel-2A MSI supervised classification on August 21, 2017.

The roads and roofs of buildings - artificial surfaces are the most heated; the surface with dense woody vegetation is much cooler; accordingly, the open water is a cool type of terrestrial surface.

As a result, thermal anomalies were detected, the localization of which is consistent with changes in the type of land cover (Fig. 5).

The analysis of the minimum, maximum and average temperatures for each class and for the whole territory was performed (Table 4). Since the temperature of green areas is less than the temperature of artificial coatings, 


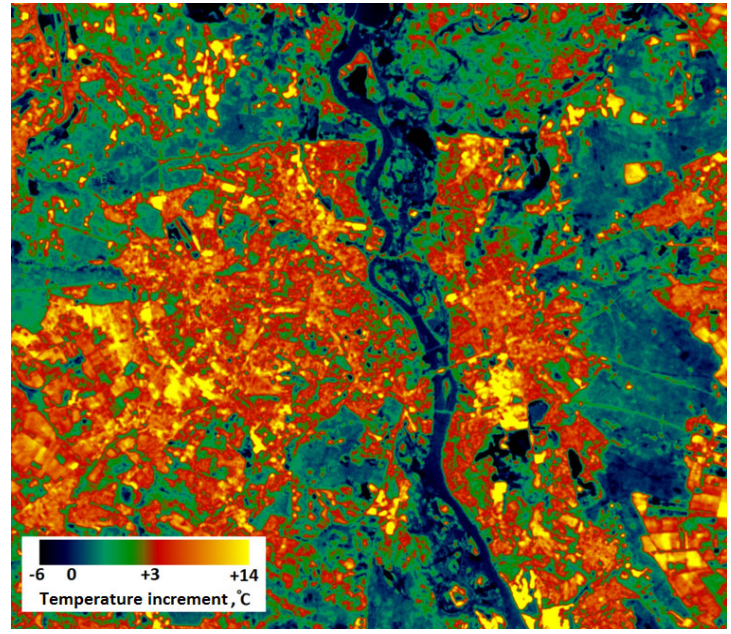

Fig. 4. Increments in surface temperatures based on the processing of long-term Landsat- 8 data series for the Kyiv city for the period 19852018
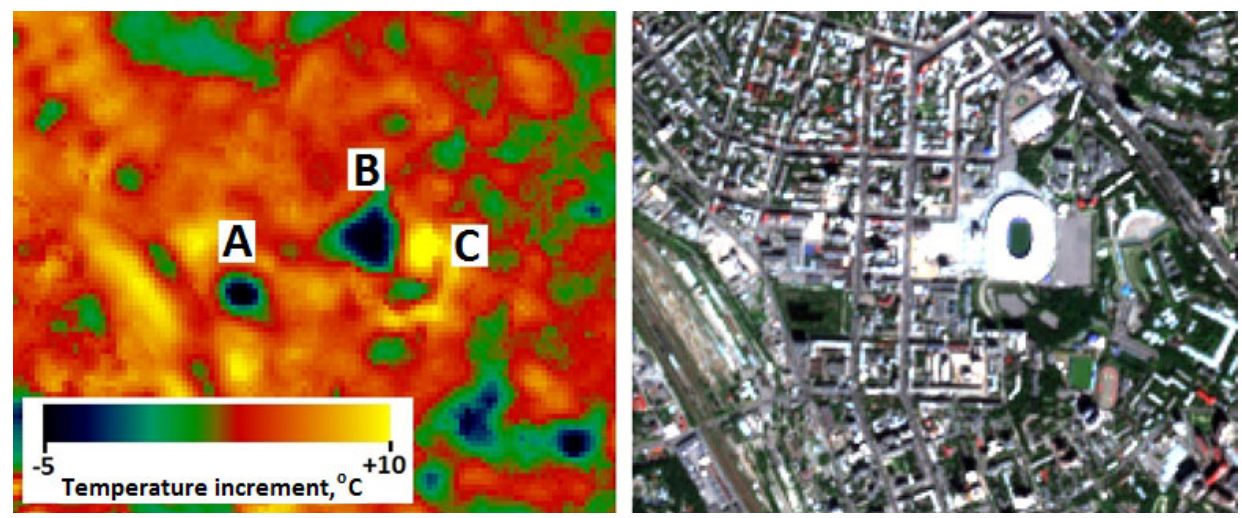

Fig. 5. Increments in surface temperatures based on the processing of a time series of Landsat- 8 data for the 1985-2018 period . The neighbourhood of "Olympic" national sport center (Kyiv) example: a - lowering the temperature due to the elimination of the tram depot them. T. G. Shevchenko on the Antonovich Street and flooding the territory; b - lowering the temperature due to the reconstruction of the Republican stadium; c - temperature increase due to the construction of a large packaging site

Table 4.

Temperature analysis of the test area

\begin{tabular}{llrllll}
\hline № & Class & $\%$ & $\mathrm{~T}_{\text {min }}\left({ }^{\circ} \mathrm{C}\right)$ & $\mathrm{T}_{\text {mx }}\left({ }^{\circ} \mathrm{C}\right)$ & $\mathrm{T}_{\text {mean }}\left({ }^{\circ} \mathrm{C}\right)$ & NDVI $_{\text {mran }}$ \\
\hline 1 & Roofs & 33.5 & 29.8 & 44.9 & 36.9 & 0.12 \\
2 & Roads & 38.9 & 29.7 & 44.9 & 37.4 & 0.12 \\
3 & Vegetation & 24.9 & 27.8 & 43.5 & 33.9 & 0.72 \\
& Overall territory & 100.0 & 27.8 & 44.9 & 36.3 & 0.28 \\
\hline
\end{tabular}

the obtained indicators confirm the positive effect of an increase in the areas covered with vegetation on the average temperature of the studied area.

The heterogeneity of the urban environment, the differences in planning due to historical development, create different temperature regimes in each region and even in a micro-district of a large metropolis. For the temperatures analysis and the impact of the green spaces number and other land covers types, three test plots within the Kyiv city were selected: Troeschina, Otradny Avenue, and Osokorki.

A detailed classification of the main land cover types was carried out and the main classes for analysis were selected: artificial surfaces, vegetation, and water surface. The comparison results are presented in Table 5.

In general, the highest temperatures are characteristic of industrial areas (Obolon, Minsk Massif, Darnitsa industrial areas, the vicinity of railway lines, the International Exhibition Center). Due to the high concentration of metal and bitumen roofs, asphalt roads and the virtual absence of vegetation, the surface temperature on a sunny day reaches $46^{\circ} \mathrm{C}$. Such areas are the largest accumulators of thermal energy and, accordingly, have the greatest impact on the microclimate of the city at night, giving off heat to atmospheric air after sunset.

It should also be noted a significant difference in 
Table 5.

Comparative analysis of test sites temperature

\begin{tabular}{lcccc}
\hline Class & Area $\%$ & $\mathrm{~T}_{\text {min }}\left({ }^{\circ} \mathrm{C}\right)$ & $\left.\mathrm{T}_{\text {max }}{ }^{\circ} \mathrm{C}\right)$ & $\mathrm{T}_{\text {me an }}\left({ }^{\circ} \mathrm{C}\right)$ \\
\hline \multicolumn{5}{c}{ Troyeshchyna } \\
Roads & 29.7 & 30.3 & 46.5 & 39.1 \\
Roofs & 22.0 & 28.4 & 47.3 & 38.5 \\
Woody vegetation & 26.1 & 25.5 & 43.8 & 32.9 \\
Grass vegetation & 15.1 & 27.7 & 45.1 & 37.3 \\
Water su ffaces & 4.8 & 26.4 & 41.6 & 32.5 \\
& \multicolumn{5}{c}{ Otradny Avenue } & & \\
Roads & 26.1 & 30.9 & 46.3 & 38.3 \\
Roofs & 43.6 & 30.9 & 46.3 & 38.3 \\
Woody vegetation & 26.4 & 28.8 & 45.1 & 34.6 \\
Grass vegetation & 2.7 & 29.2 & 41.8 & 34.2 \\
& \multicolumn{5}{c}{ Osokorki } & & \\
Roads & 37.0 & 26.4 & 46.1 & 37.1 \\
Roofs & 31.7 & 26.5 & 46.1 & 36.6 \\
Woody vegetation & 14.0 & 25.6 & 42.1 & 33.4 \\
Grass vegetation & 6.3 & 29.1 & 44.5 & 36.6 \\
Water surfaces & 7.6 & 24.7 & 38.7 & 28.4 \\
\hline
\end{tabular}

surface temperatures between micro-districts with moderately dense woody vegetation and with areas where it is practically absent. Thus in areas with a low density of woody vegetation (Troyeshchina, Kharkov array) surface temperature distribution according to the RS is in the range $36-39^{\circ} \mathrm{C}$, while areas with thick woody vegetation (Lisoviy, Darnitsya) the temperature ranges from $34-36^{\circ} \mathrm{C}$. The presence of forest parks also has a positive effect on the temperature regime of the area. So, for example, in areas surrounded by park zones (Solomianka and Batiyeva Gora micro-districts) temperatures range from 33 to $35^{\circ} \mathrm{C}$. The temperature of tree crowns within forests and parks is within 26 to $28^{\circ} \mathrm{C}$. Forest cuttings expose soil and surface vegetation covers and, accordingly, increase the surface temperature by $6-8^{\circ} \mathrm{C}$. In addition, high temperatures were found in areas with malls, large parking areas $\left(40-43^{\circ} \mathrm{C}\right)$. In the central part of planting through courtyards, surface temperature is in the range $34-37^{\circ} \mathrm{C}$.

This example confirms both the negative impact of unorganized urbanization on the environment and its impact on the urban microclimate, as well as the positive effect of greening the city, both within the districts and due to separate areas for forest-park zones.

\section{Conclusions and recommendations}

The use of thermal radiation emissivity distribution obtained using data of the visible and near infrared bands can significantly improve the information content of the resulting temperature distribution images. Subpixel processing of the pairs of lowresolution thermal emissivity distribution achieves the resolution enhancement by $46 \%$. Taken together, this two-step approach allows obtaining the distribution of the thermal field of a significantly higher spatial resolution as compared with the technical performance of the currently existing sensors of long-wave infrared radiation. This approach will allow conducting detailed studies of heterogeneous areas, for example, urbanized environment, to more accurately track hot heat sources and the dynamics of the thermal field caused by deforestation, buildings development, sand reclamation and any other natural or anthropogenic drivers. As a result, this approach provides the possibility for development the more accurate and in-depth forecasts microclimate changes, which is especially important in today's rapid development of urban and industrial landscapes.

As a result of a comparative analysis of the distribution of surface temperature and land cover classes of the city, the positive impact of greening the city was confirmed. In addition, according to the classification results, the following thermal anomalies were established:

- the highest temperatures are typical for residential and industrial areas (Obolon, Minskiy, industrial zone Darnytsa district, railway junction, the International Exhibition Center);

- there is a significant difference in surface temperatures between built-up housing estates and planted woody vegetation. So in areas with low density of woody vegetation (Troyeshchyna, Kharkiv massif), the distribution of surface temperatures according to remote sensing data is within $36-39^{\circ} \mathrm{C}$, while in areas with dense woody vegetation (Forest, Darnitsa) the temperature varies within $34-36^{\circ} \mathrm{C}$;

- high temperatures were found in areas with shopping and entertainment centres, large packing sites $\left(40-43^{\circ} \mathrm{C}\right)$;

- in the central part of the city, thanks to the landscaping of courtyards, the surface temperature is between $34-37^{\circ} \mathrm{C}$.

In order to reduce thermal pollution in the city it is recommended: 
- use dyes of light colors for roofs, whose albedo is much higher with similar insulating properties, with respect to dark colors;

- implement the technology of "green roofs", whose functions are to absorb heat, filter air, and also retain infiltrated water;

- for pavement, use a mixture of cement with light substances;

- increase the area of green plantings, the efficiency of which is confirmed in this study;

- construct pedestrian roads using materials characterized by a high degree of moisture permeability;

- create a small "green" zone, exempt from vehicles.

\section{Acknowledgement}

This research was supported by the National Academy of Sciences of Ukraine (grant for research project of young scientists by NAS Presidium decision No. 178 of 14.06 .2017$)$.

We thank Prof. S. A. Stankevich and Dr. V. E. Filipovich for their help in the research objective formulation and technological solutions development. We thank Dr. Dugin S. S. for technical and methodological support of field measurements.

\section{References}

1. Bottillo, S., Vollaro, A., Galli, G., Vallati, A. (2014). Fluid dynamic and heat transfer parameters in an urban canyon. Solar Energy. 99, 1-10.

2. Chander, G., Markham, B. L., Helder, D. L. (2009). Summary of current radiometric calibration coefficients for Landsat MSS, TM, ETM+, and EO-1 ALI sensors. Remote Sensing of Environment. 113 (5), 893-903.

3. Denisik, G. I., Kyzyun, A. G. (2011). Residential landscapes: terms and concepts, their essence and legitimate use. Naukovi zapysky Vinnycjkogho peduniversytetu. Ser. Gheoghrafija. 22, 5-9. Retrieved from: http://nbuv.gov.ua/ UJRN/Nzvdpu_geogr_2011_22_3.(Ukrainian).

4. Gornyy, V. I., Kritsuk, S. G., Latypov, I. Sh., Tronin, A. A., Kiselev, A. V., Brovkina, O. V., Filippovich, V.E., Stankevich, S. A., Lubskyi, N. S. (2017). Thermophysical properties of land surface in urban areas (by satellite remote sensing of Saint Petersburg and Kiev).Sovremennye problemy distantsionnogo zondirovaniya Zemli iz kosmosa. 14 (3), 51-66. (Russian).

5. Gornyy, V. I., Lyalko, V. I., Kritsuk, S. G., Latypov, I. Sh., Tronin, A. A., Filippovich, V. E., Stankevich, S. A., Brovkina, O. V., Kiselev, A. V., Davidan, T. A., Lubskyi, N. S.,
Krylova, A. B. (2016). Forecast of Saint-Petersburg and Kiev thermal replies on climate change (on the basis of EOS and Landsat satellite imagery). Sovremennye problemy distantsionnogo zondirovaniya Zemli iz kosmosa. 13 (2), 176-191. (Russian).

6. Hafner, J., Kidder, S. Q. (1998). Urban Heat Island Modeling in Conjunction with Satellite-Derived Surface/Soil Parameters.Journal of Applied Meteorology. 38, 448-465.

7. Li, H., Meier, F., Lee, X., Chakraborty, T., Liud, J., Schaap, M., Sodoudi, S. (2018). Interaction between urban heat island and urban pollution island during summer in Berlin. Science of the Total Environment. 636, 818-828.

8. Nuruzzaman, Md. (2015). Urban Heat Island: Causes, Effects and Mitigation Measures - A Review. International Journal of Environmental Monitoring and Analysis. 3 (2), 67-73.

9. Piestova, I., Lubskyi, M., Svideniuk, M., Golubov, S. (2017, december). Thermal micro-mapping of urban area using infrared satellite imagery. Gheoprostir-2017: materialy mizhnarodnoji nauk.-tekhn. konf, (pp. 80-82), Kyiv: KNUBA. (Ukrainian).

10. Piestova, I., Lubskyi, M., Svideniuk, M., Golubov, S., Sedlacek, P. (2018). Satellite Imagery Resolution Enhancement for Urban Area Thermal Micromapping. Central European Researchers Journal. 4 (1), 35-39.

11. Schwarz, N., Lautenbach, S., Seppelt, R. (2011). Exploring indicators for quantifying surface urban heat islands of European cities with MODIS land surface temperatures. Remote Sensing of Environment. 115 (12), 3175-3186.

12. Stankevich, S. A., Filippovich, V. E., Lubsky, N. S., Krylova, A. B., Kritsuk, S. G., Brovkina, O. V, Gornyi, V. I., Tronin A. A. (2015). Intercalibration of methods for restoring the thermodynamic temperature of the surface of an urbanized area based on materials of thermal space imagery. Ukr. $\check{z}$. distancìjnogo zonduvannâ Zemlì. 7, 12-21. Retrieved from https://ujrs.org.ua/ujrs/article/view/59/77.

13. Stankevich S. A., Lubskyi M. S. (2018, April). Application of visible and NIR remote sensing data for deriving of Earth's surface thermal fields of high spatial resolution. roceedings of the XII conference Telecomunication problems-2018, (pp. 329-331), Kyiv. Ukraine.

14. Stankevich, S. A., Pilipchuk, V. V., Lubsky, M. S., Krylova, G. B. (2016). Evaluation of the accuracy of determining the temperature of artificial and natural earth surfaces based on the results of infrared satellite imagery. Space science and technology. 101 (4), 19-28.

15. Tang, H.,Li, Z.-L. (2014). Quantitative RemoteSensing in Thermal Infrared: Theory and Applications. Berlin: Springer-Verlag.

16. Urroz, G. E. (2001). Time Series and Spatial Data Analysis with SciLab. Logan: InfoClearinghouse. 
ТЕПЛОВЕ МІКРОКАРТУВАННЯ МІСЬКИХ ТЕРИТОРІЙ 3 ВИКОРИСТАННЯМ КОСМІЧНИХ ЗНІМКІВ ТА ПОЛЬОВИХ ЗАВІРКОВИХ ВИМІРЮВАНЬ НА ПРИКЛАДІ МІСТА КИЕВА

І. О. Пєстова, М. С. Лубський, М. О. Свіденюк, С. І. Голубов, О. А. Лаптєв

Дане дослідження спрямоване на вдосконалення підходу до оцінки теплового режиму міста в умовах кліматичних змін за допомогою багатоспектральних супутникових даних на прикладі міста Київ.

у роботі описано метод та результати обчислення температури та коефіцієнтів теплового випромінювання земної поверхні. Зокрема, відповідно до закону Планка для “cipoго тіла”, за супутниковими даними Landsat-8 TIRS та Sentinel-2 MSI було обчислено розподіл температур через спектральну густину потоку випромінювання. Крім того, результати обчислення було калібровано за даними наземних підсупутникових вимірювань температури та коефіцієнта теплового випромінювання типових покривів міста.

Просторову розрізненність отриманих розподілів температури земної поверхні було підвищено за методом субпіксельної обробки, для чого було використано пари субпіксельно зміщених інваріантних зображень. В результаті, даний підхід дозволив підвищити просторову розрізненність зображення на 46\%, що значно вища у порівнянні з технічними можливостями нині існуючих сенсорів довгохвильового інфрачервоного випромінювання.

Взаємозв'язок між типом та температурою земного покриву було встановлено за результатами керованої класифікації багатоспектрального знімка Sentinel-2А за 21 серпня 2017 року. Таким чином, виділено шість основних земних покривів міського середовища: дахи будівель, дорожні покриття, відкритий грунт, трав'яна рослинність, деревна рослинність та вода. В результаті, температура поверхонь покритих рослинністю виявилась значно нижчою за температуру штучних покриттів. Для дослідження просторово-часових змін поверхневої температури міського середовища, здійснено аналіз часової серії з 18 теплових зображень (Landsat-5 TM та Landsat-8 TIRS) міста Києва за період з 6 червня 1985 року по 1 червня 2018 року. Таким чином, виявлено температурні аномалії, виникненню яких сприяла зміна ландшафту, зокрема: спорудження нового НСК “Олімпійський” та прилеглого паркувального майданчику призвело до підвищення теплового поля; з іншого боку, ліквідація трамвайного депо ім. Т. Г. Шевченка та подальше підтоплення ділянки призвело до підтоплення ділянки, спричинило пониження температури.

ключові слова: тепловий режим міста, температура земної поверхні, коефіцієнт теплового випромінювання, тимчасові ряди

\section{ТЕПЛОВОЕ МИКРОКАРТИРОВАНИЕ ГОРОДСКИХ ТЕРРИТОРИЙ С ИСПОЛЬЗОВАНИЕМ КОСМИЧЕСКИХ СНИМКОВ И ПОЛЕВЫХ ИЗМЕРЕНИЙ НА ПРИМЕРЕ ГОРОДА КИЕВА}

И. А. Пестова, Н. С. Лубский, М. О. Свиденюк, С. И. Голубов, А. А. Лаптев

Данное исследование направлено на усовершенствование подхода к оценке теплового режима города в условиях климатических изменений при помощи многоспектральных спутниковых данных на примере г. Киев.

В работе описан метод и результаты расчета температуры и коэффициентов теплового излучения земной поверхности. B частности, в соответствии с законом Планка для "серого тела", по спутниковым данным Landsat-8 TIRS и Sentinel-2 MSI было рассчитано распределение температур через спектральную плотность потока излучения. Кроме того, результаты расчёта были калиброваны по данным наземных “подспутниковых" измерений температуры и коэффициента теплового излучения типичных городских покрытий.

Пространственное разрешение полученных распределений температуры земной поверхности было повышено методом субпиксельной обработки, для чего были использованы пары субпиксельно смещенных инвариантных изображений. В результате, данный подход позволил повысить пространственное разрешение изображения на 46\%, что значительно выше в сравнении с техническими возможностями сегодня существующих сенсоров длинноволнового инфракрасного излучения. Взаимосвязь между типом и температурой земного покрытия была установлена по результатам управляемой классификации многоспектрального изображения Sentinel-2А за 21 августа 2017 года. Таким образом, было выделено шесть основных земных покрытий городской среды: крыши домов, дорожные покрытия, открытые почвы, травянистая растительность, древесная растительность и вода. В результате, температура поверхностей, покрытых растительностью, оказалась значительно ниже температуры штучных покрытий

Для исследования пространственно-временных изменений поверхностной температуры городской среды, был проведен анализ временного ряда 18 тепловых изображений (Landsat-8 TIRS и Landsat-8 OLI) города Киева за период с 6 июня 1985 года по 1 июля 2018 года. Таким образом, выявлено температурные аномалии, возникновению которых поспособствовало изменение ландшафта, в частности: сооружение НСК “Олимпийский” и прилегающей парковочной площадки привело к повышению теплового поля; с другой стороны, ликвидация трамвайного депо им. Т. Г. Шевченко и дальнейшее подтопление участка привело к понижению температуры.

ключевые слова: городской тепловой режим, температура земной поверхности, коэффициент теплового излучения, временные ряды 